\title{
Religion and spirituality: What are the fundamental differences?
}

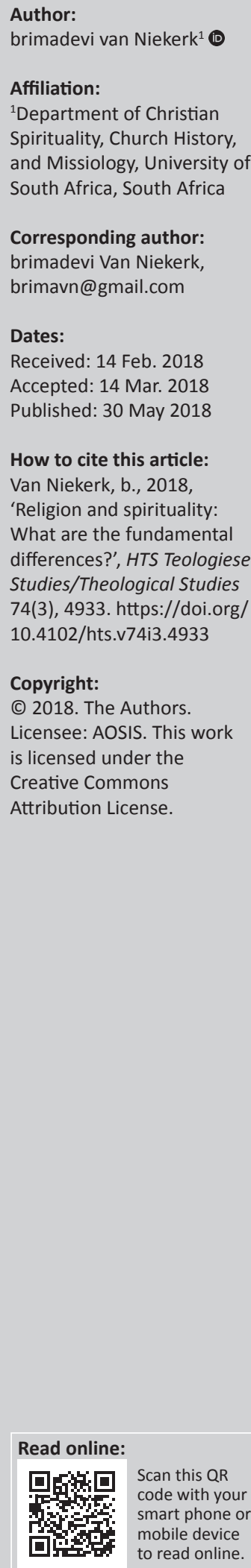

\begin{abstract}
Some Victorian evolutionary thinkers, such as James Frazer, theorised that humanity's mental stages are characterised by magic, followed by religion, culminating in science. Put another way, the notion of humanity's encounter with the sacred in society will eventually retreat, giving way to secular conditions, and that science and rationality would triumph as a more persuasive means of satisfying human needs. In this first foray in explorations on spirituality and religion, this article asks what the fundamental differences between religion and spirituality are, and will examine the aspects of spirituality that are freely accessible and freely chosen and that are uneasy with religion, by looking at some of the constructed borders that result in religion becoming narrow, rigid, prescriptive and less attractive. The article then examines how the phenomenon of spirituality is creating new paradigms of consciousness. It draws on the literature on religion, spirituality, sociology and anthropology, and concludes that religion will not go away despite the efforts of secularisation.
\end{abstract}

\section{Introduction}

Some Victorian evolutionary thinkers, such as James Frazer, theorised that humanity's mental stages are characterised by magic, followed by religion, culminating in science. Put another way, the notion of the human encounter with the sacred in society will eventually retreat, giving way to secular conditions, and that science and rationality would triumph as a more persuasive means of satisfying human needs. Durkheim (1915) also predicted that modern society will ultimately have no need for religion and that rational thinking and secular institutions would replace religion. Modernity, he argued, would be taken over by rationalisation and as religion declined society would develop into a more complex form. Well, they were wrong. Many modern scholars continued to predict that with growth in literacy, travel, diaspora movements, advancements in technology, mass media and communication, religion would decline. However, while the effects of modernity may have undermined the cohesive force of religion, we now know that religion is here to stay and that the sacred presents itself in 'new' ways.

The religious mind has a certain uneasiness with the notion of spirituality as a concept standing by itself or being observed and studied in an independent way. What is this uneasiness? Is it that it suspects spirituality of Pelagian notions of human beings which deny the doctrines of original sin and predestination, and lays claim to a moral perfection which is attainable in this life through human free will without the assistance of divine grace? Is it, also, because humans and their own affairs are given centre stage? Another difficulty with the concept of spirituality is the pursuit of any attempt to distinguish it as a distinct form of identity from religious identity. Why exactly are people, who were once-upon-a-time religious, dissatisfied with religion, and what are they converting to?

Over 100 years ago, the consequences of the French Revolution culminated in the law of 1905 which created a separation of church and state. Unlike the Enlightenment in Germany, the brand of Enlightenment produced in France was 'uncompromisingly secularist', epitomised in philosopher and encyclopaedist Denis Diderot's call: 'Have the courage to flee from the yoke of religion so that one may regain one's humanity, be oneself' (quoted in Cassirer 1968:135). While religion was not officially suppressed in the West, there was a general attitude that the world would secularise and adopt rationality as a more persuasive means of satisfying human needs. Weber (1963 [1922]:270) argued that the character of the modernised, bureaucratic, secularised society was one where scientific understanding would be more highly valued as the society moved towards rational goals. This would lead to secularisation and the decline of magic and belief. Traditional society, he argued, would 'remain an enchanted garden', where fetishist practices and rituals would continue. However, as religion became 
more rational, the world would become exactly the opposite of enchanted; it would become demystified. Criticism of religion was also widespread in the academy from various disciplines, including anthropology, economics, psychology and sociology (Borowik 2011:175176). In central and eastern Europe after the Russian revolutions of 1905 and 1917, religion was expressly suppressed by the state. This may be a broad generalisation because it was only after 1945 when the Soviets occupied the eastern European states that the full suppression of religion in those countries was implemented. This largely continued until the collapse of communism. In the West, according to Borowik (2011:178), changes in attitude towards religion began in the 1960s. However, as Borowik (2011:180) argues, the contemporary view of religion appears to have been reversed with a widespread view that the sacred, whether expressed in religion or spirituality, is here to stay, prosper and flourish.

But as Susanne Hoeber Rudolf (quoted in Strenski 1998:131) argues, 'modern social science did not warn us that these transnational identifications would arise'. Instead, it asserted that religion would fade, then disappear, with the triumph of science and rationalism, but in reality religion had expanded explosively, stimulated as much by secular global progress - migration, multinational capital, the media revolution - as by proselytizing activity. It was unexpected, she says, and 'its expansion has been the answer to the deracination and threats to cultural extension associated with modernization processes, religious experience seeks to restore meaning to life'. Although Peter Berger (1967:138-139), writing in the late 1960s, had already said that 'secularisation brings about a demonopolisation of religious traditions and thus, ipso facto, leads to a pluralistic situation'.

It was Wade Clark Roof's study, A Generation of Seekers (1993), that made scholars aware that the religious landscape had shifted yet again. The aim of his study was to examine how boomers, since shortly after the Second World War, may be transforming religion and spiritual life; how they related to the sacred; and what this would mean for the future trends of religion (Roof 1993:6). ${ }^{1}$

Roof (1993:1) spelt out the different religious activities in the decades beginning with the 1960s that show change and transformation:

The turbulent 1960s: the Age of Aquarius. From mid-1770s to late 1970s - a time of evangelical and charismatic revival. The 1980s were characterised by a smorgasbord of New Age Spiritualities. And from hippies in the 1960s to Yuppies in the 1980 s. $^{2}$

1.While Wade's research results are based in US communities, and cannot be taken as universally representative, his work is important because it has implications for universaly rese re modernity and the distinctive religious change that has taken place in the recent past, as well as the de-institutionalisation of religion. These ideas will have implications for all scholars working in the field of religion, whether in Europe or

2.Yuppie is an acronym coined in the 1980 s, referring to a young urban professional.
His (Roof 1993) findings show that these baby boomers were a 'generation of seekers'. As:

diverse as they are - from Christian fundamentalists to radical feminists, from New Age explorers to get-rich-quick MBAs baby boomers have found that they have to discover for themselves what gives their lives meaning, what values to live by. (p. 6)

It would appear that the catastrophe of the war had altered the way in which religion was handed down from parents to children. That is to say, that the values and traditions were not passively being accepted as a fait accompli - there was active appropriation. Roof (1993:8) concluded that these boomers 'value experience over beliefs, distrust institutions and leaders and stress fulfilment yet yearn for community, and are fluid in their allegiances - a new, truly distinct, rather mysterious generation'.

However, while changes were taking place not only in how people responded to the sacred but also in how they took responsibility for that relationship, religion, none the less, has persisted. Reinhold Niebuhr (1968) asked, 'why has religious faith persisted for three centuries after the first triumphs of modern science?' 'Religion', he affirmed:

is continually renewed out of the incongruous situation of man he is a child of nature who yet transcends nature, a creature who experiences disorder and incoherence but who also thinks about it and struggles with it. (Niebuhr 1968:x)

Similarly, Preuss (1987:xviii) argues that the question of why there is religion at all, its prevalence, its tenacity or its ability to change modes are all questions we cannot do away with.

And so we must ask, what is religion?

\section{What is religion?}

The word 'religion', according to Ramsey and Ledbetter (2001:2), 'is not a neutral, descriptive term but has strong overtones of a political and moral nature'. Cicero derived 'religion' from relegere, to re-read. In other words, 'that which is re-read', that which is passed along chains of tradition. Alternatively, Lactantuis traces religion to religare, 'to bind fast' or that which binds men and women to one another and to the gods. Etymologically then, 'religion' has a strong emphasis on community, which is ironic given the tendency in the modern world to think of religion as something private and personal (Ramsey \& Ledbetter 2001:2).

However, if we treat the concept of religion as an object, then the first thing the intellect does with an object is to group it with some other object or differentiate it from other objects. But, as James says (1929:10), 'any object that is infinitely important to us and awakens our devotion feels to us also as if it must be sui generis and unique'. 'Probably a crab', he continues, 'would be filled with a sense of personal outrage if first of all an experience sui generis, incited by man's encounter with the sacred'. 
it could hear us class it without ado or apology as a crustacean, and thus dispose of it, "I am no such thing", it would say, "I am myself, myself alone".

How then is religion to be defined? And like Brian Wilson (1998:143) one can ask why scholars put so much effort 'to consciously construct' a 'reasoned definition' of religion which he argues was essentially an Enlightenment enterprise. In answering the question about what religion is, does it reflect the 'multi-faceted nature of religion?' (Ramsey \& Ledbetter 2001:2). And when religion is defined, whose religion is being defined? For as Caputo (2000:1) says, 'there are Western religions, Eastern religions, ancient religions, modern religions, monotheistic, polytheistic, and even slightly atheistic religions'. And apart from the immense and bewildering diversity of religions, they appear to each have a particular language which one has to learn in order to understand them. Perhaps this diversity or what Caputo (2000:1) calls the "uncontainable diversity of "religion" is itself a great truth and a marker of the uncontainability of what religion is all about'. Added to this are the different cultural and social backgrounds, different socio-economic and political situations and varied psychological conditionings which may well contribute to the diversity of religion and religious experience. And yet another problem related to a methodological issue drawing from Smart (1977:11): Who are we addressing this explanation of religion to? Furthermore, the term appears to be ambiguous, inconclusive, polyvalent, and there have been, over the years, various scholars and teachers who have in their writing and pedagogical exercises expressed the general view that the subject of religion as a concept is difficult to define and is further obstructed by the language in which the ideas of the concept are conveyed.

Mircea Eliade (1969:preface) has bemoaned the fact that we don't have a more exact or accurate word for religion that would express the relationship between man and the sacred. The term religion, he says, 'carries with it a long, although culturally rather limited, history'. His concern relates to how we may 'indiscriminately' apply the term to other religions and religious systems such as Buddhism, Confucianism and so on. But he surrenders his need for a new term with a proviso that our definition of religion 'does not necessarily imply belief in God, gods, ghost, but refers to the experience of the sacred, and, consequently, is related to the ideas of being, meaning, and $t r u t h '$. Clearly, then, for Eliade, experience is paramount in understanding the concept of religion.

But perhaps we would do well to take on board DiCenso's (1998:15) understanding of the word religion. He says that we should see the term as an 'umbrella term describing sets of highly differentiated and multi-faceted phenomena straddling psychology and culture across huge divides of time and space' and that it 'simply cannot be embraced by a single interpretative approach no matter how complex'. We may, he continues:

grant that no single type of theory can do justice even to a single religious tradition, let alone to the staggering diversity of the global and historical variants of religion. Indeed, to speak of 'religion' is already to engage in abstraction. (DiCenso 1998:15)

With that, here, briefly, are some of the difficulties with defining and conceptualising religion. In the literature, the theories of religion show that most definitions are achieved not by exhaustive empirical study but, rather, by singling out one or other attractive or compelling feature of religious practice. For example, A.N. Whitehead's (1926) views on 'what a man does with his solitariness', Paul Tillich (1959:7-8) who asserted that religion is one's 'ultimate concern' or Tylor's (1891:424) rudimentary definition of religion, 'belief in spiritual beings', which he believed to be the essence of religion. These definitions are pithy but, yet, not nuanced and conclusive; it points to one out of the many characteristics of religion.

Scholars who tease out different aspects of religion either say what religion does, that is to say, by defining it according to its social and psychological functions, or what religion is, that is to say, by its belief content. Durkheim (1915), who first studied religion as a social phenomenon among the Australian Aboriginals, has combined the content of religion with the primary functions of religion in an equation that produces social consequences, thereby fortifying the communal and social aspects of religion. For Durkheim, the question about what religion is, its function, its characteristic parts and the things that give rise to religion and its resultant consequences cannot be known or anticipated before a study is complete, referring, of course, to his Elementary Forms of the Religious Life. Durkheim was acutely aware that religions may be defined by how they were viewed in the past or how they are in the present; but, he argues, it is not possible to define them as they will be in the future. Indeed, Durkheim (1915) is aware that religion is a process and that it is everchanging. Thus:

A religion is a unified system of beliefs and practices relative to sacred things, that is to say, things set apart and forbidden beliefs and practices which unite into one single moral community called a church, all those who adhere to them. (p. 47)

While the effect of this definition of religion dichotomises and makes a distinction between the sacred and the profane realms of reality, it also reveals the necessity for the social in society. D. Bruce Mackay (2000) interprets Durkheim as saying that the:

role of ritual performed by members of the society, therefore, was to inculcate the values of the society, to renew the sense of belonging to that society, and to maintain and uphold the community. (p. 99)

But there was still the aspect of experience, among other features missing from the definitions I have noted above.

In his now classic study on The Varieties of Religious Experiences, William James turned to classical and contemporary written accounts generally deemed to be 'religious' and who was the first to assert that there are as many different forms of religious experience as there are multiple ways in which 
these experiences can be expressed. On religion, James (2002 [1902]:26) said 'the very fact that there are so many and so different from one another is enough to prove that the word "religion" cannot stand for any single principle or essence but is rather a collective name'. The theorising mind, says James, tends always to oversimplify its materials which are the source of fixed, unchangeable, non-variable, and nonrelative doctrine. There is 'no one essence, but many characters which may alternately be equally important in religion' (2002 [1902]:31). He defined religion as 'the feelings, acts, and experiences of individual men in their solitude so far as they can apprehend themselves to stand in relation to whatever they may consider divine' (James 2002 [1902]: 29-30). Like Whitehead, the emphasis for James was on the solitude, placing emphasis most notably on the subjective and personal dimensions of religious experience, making experience idiosyncratic to religion captured in the phrase: 'to stand in relation to ... the divine'. ${ }^{4}$

This may take many forms: cognitive, ritual, inspirational, transformative and sustaining. The inward and transformative or unifying character of a type of experience may be generally termed mysticism. What James concludes about all the varieties of religious experiences that he studied is that 'there is something wrong about us as we naturally stand' and that 'we are saved from wrongness by making proper connection with higher powers [the transcendent]' (2002 [1902]:498). Of course, James is aware that when dealing with the sacred using the word 'divine' can be controversial, especially when narrow definitions are employed. There are 'systems of thought' which are usually called religious but they do not contain a God. Buddhism is one case in point. Although 'the Buddha himself stands in the place of a God', in a strict sense the 'Buddhistic system is atheistic'.

This then makes it rather difficult to categorise Buddhism. Is it a religion or is it not? Is there also a word for religion within this tradition? And why place Buddhism into any category that is knowable or understandable? Again, the problem of how to define arises. How is a Western understanding of religion used as an operating paradigm when approaching Eastern religions, philosophical systems and so on? Buddhism may well represent an idea of a different form of theism and not the Semitic theistic framework that is readily employed when trying to define religious traditions of the East. ${ }^{5}$

\footnotetext{
4.0tto (2003:109) gives credit to Schleiermacher for his idea of 'feeling of dependence' Both thinkers ground religion in an original experience or the 'numinous'. However, Otto elaborated on Schleiermacher's thinking by expanding his notions on religious emotions. Otto (1958) insisted that there was no religion without this innermost core - the personal experience of the sacred emphasises the non-rational characte of religion. Otto was referring to the Other - the mysterium tremendum or the mysterium fascinans - expressions of the sacred lodged in experience.

5.Similarly, when one encounters African religions, one is faced with the problem of definition. Beyer (2006:266-267) addresses the issue of how African traditional religion is constructed into a religion. Trying to consolidate it under an umbrell name is problematic - there are too many languages and linguistic and cultura groups who practice African traditional religion. It is difficult trying to find out what belongs to the religion and what does not. Especially as he argues that 'religion does not become solidly incorporated into that system unless it is explicitly formed as one of the religions, recognised by outsiders and constructed by insiders (Beyer 2006:266-267)
}

Yinger's take on religion has some overlapping features with Durkheim's, namely, beliefs, practices and community. Yinger (1970:4) therefore defines religion as 'a system of beliefs and practices by means of which a group of people struggles with these ultimate problems of human life'. For Yinger (1970:27), religion should not be thought of in a logical and consistent way, having 'sharp boundaries', but as 'a somewhat imprecise bundle of rites, beliefs, knowledge, and experiences. For primitive societies the unitary way of looking at religion is more nearly adequate'.

In the 1960s and the 1970s, the understanding of religion in terms of beliefs and practices as features of religion was less important and the concept of culture took prominence, evident in the approaches to religion which interpret it as an all-embracing system of meaning which covers the whole of life. Two scholars exemplify this approach, namely, Peter Berger (1969) and Clifford Geertz (1971). In The Sacred Canopy (1969), Berger said that there was little point arguing over definitions. He saw them as ad hoc constructs and he noted that his basic attitude towards them was one of a 'relaxed ecumenical tolerance'. For Berger, religion provides a system of meaning for making sense of the world, and for covering contingency with a canopy of sacrality.

Geertz (1971:125) too advocated that an analysis of the 'system of meanings embodied in the symbols which make up religion proper' take place and how these relate to socialstructural and psychological processes, encapsulated in his definition:

a system of symbols which acts to establish powerful, pervasive and long-lasting moods and motivations in men by formulating conceptions of a general order of existence and clothing these conceptions with an aura of factuality that the moods and motivations seem uniquely realistic. (p. 90)

Geertz (1971:5), however, went deeper with the use of his methodological tool of 'thick description'. He was not satisfied with simply describing the structure of a tribe or the 'bare elements' of ritual, or for that matter to say that Muslims fast in the month of Ramadan. He wanted scholars to 'discover meanings and intentions behind what people do, and the significance of all of life and thought in their rituals, structures, and beliefs'.

I wonder if Geertz was trying to get to the unobservable features of religion when he suggested that we should go behind all that is observable. Similarly, Idinopulos (1998:27) calls for a 'rationality-based academic study of religion' to be based on 'what is observable'; but, he says, 'religion is not exhausted by the observable'. And I think that is what so many of the earlier conceptualisations of religion seem to miss - all the features named about religion do not seem to mention those aspects which are not tangible. Idinopulos (1998) observes that:

there is another dimension, which is a source of religious purpose and meaning, it is the failure to recognise the difference between the observable and the non-observable, confusing one with the other, or by denying one on behalf of the other that confounds our understanding of religion. (p. 2) 
In his entry on Religion in The Encyclopedia of Religion, Winston King (1987) begins his opening sentence thus:

The very attempt to define religion, to find some distinctive or possibly unique essence or set of qualities that distinguish the 'religious' from the remainder of human life is primarily a Western concern. (p. 282)

King (1987:282) argues that the task of defining is a 'natural' result of 'Western speculative, intellectualistic, and scientific' predilection. The idea that religion is dichotomised may have its origins in the Judeo-Christian notions of theism. Inherent in the fundamental structure of this kind of theism is to separate and divide the world up into two parts which are necessarily kept apart. Hence, the distinction between the Supreme Being and everything else; the discrimination between that which creates and which is created; and, in essence, the differentiation and separation between the God and human beings. ${ }^{6}$

Wherein lies the problem of such dichotomies and divisions? How is the sacred winnowed from the profane? Does it not mean that linguistically speaking, religion tends to be a space-holder in a series of dualisms: religion over humans, the world, unbelief, profane, spirituality and so on?

The problem, according to King (1987:282), lies apparently in the way in which language is used in these Western varieties of theism that inform and express its ideas relating to divinity. The example King (1987:282) uses to express this cleavage and differentiation in the concept of religion is the word holy. The linguistic roots of the word holy, says King (1987:82), come from notions 'signifying wholeness, perfection, wellbeing'. The opposite of holy signifies 'the fragmentary, the imperfect, the ailing'. The quality of sacredness refers to that which is set apart. Thus, that which is set apart is not associated with the ordinary and the mundane aspects of life - it is consecrated for religious use only. Therefore, buildings, such as the church, synagogue and mosque, are a 'concrete physical embodiment of this separation of the religious from all else' (King 1987:282). The world outside these dedicated spaces, the vicissitudes of fashion and all its concerns, fall under the secular world. What is being suggested in this linguistic travesty is that two worlds, no doubt split, prevail in one - that of the realm of the sacred and that of realm of the profane, or that which is outside the jurisdiction of the sacred. The repercussions of such a dichotomous world view of religion has institutional consequences, thus severing those aspects such as religious rituals, sacraments, sacred books, objects of worship, religious high days, places and spaces of worship, religious vestiture, from the mundane, prosaic and ordinary. Conceptually speaking, all religious beliefs and their ensuing practices, behaviours and institutions are on the side of the sacred.

6.Writing earlier, the structuralist mindset of Mary Douglas (1966.53) is able to see the patterned arrangements of distinction and separation. Accepting the root word of holy as 's a of holy as 'set apart', she formulates an argument to suggest that this holiness requires individuals, referring to Israelites, to conform to the class to which they belong. As such, holiness requires that things should not be confused with thing that are not holy, hence profane. Furthermore, she explains, holiness means 'keeping distinct the categories of creation', which therefore involves 'correct definition, discrimination and order'.
Following Hick (2004:9), it's important to realise that each tradition has its own vocabulary, expressing its own system of concepts, and while these overlap with those of other traditions, so that there are all manner of correspondences, parallels, analogies and structural similarities, yet each set of terms is only fully at home in its own particular linguistic environment. We have, he says, 'very little in the way of a tradition-neutral religious vocabulary'. This means that sometimes an improvisation is needed to deal with related ideas which no doubt incurs the 'wrath of the semantic workers' (Hick 2004:9).

Of course, the preceding discussion raises many questions about how one applies Western notions of the definition of religion to explain phenomena that constitute sacred practice in primitive cultures and societies where these dichotomies are less apparent. King (1987) puts it well when he says of primitive cultures:

... what the west calls religious is such an integral part of the total ongoing way of life that it is never experienced or thought of as something separable or narrowly distinguishable from the rest of the pattern. (p. 282)

Similarly, when such dichotomies are applied to a 'multifaceted entity', such as Hinduism, 'it seems like almost everything can be and is given a religious significance by some sect' (King 1987:282).

Similar problems occur, he continues, when considering other East Asian cultures such as Taoism, Confucianism and Shinto cultures. 'These cultures are characterised' by what J.J.M. de Groot (quoted in King 1987:282) has called 'universism': 'a holiness, goodness, and perfection of the natural order that has been falsified by shallow minds and errant cultural customs'. In these cultures, the sacred and secular dualities do not exist - they are one. What is suggested here is a total harmony between the supernatural world and the real world inhabited by humans. However, to critique Western dichotomist definitions of religion does not still answer the question of what religion is and what some of these definitions are premised on.

What we understand by religion seems to hinge on things that may be considered external to the core of what religion is. I think Ninian Smart (1977) may have touched on something when he said that:

so much of what we discover about religions has to do with other facts - the place and date of the birth of the Buddha or of Muhammad, the geographical spread of a faith, the items of belief listed in a creed or formula, the kind of building used and so forth. (p. 11)

However, while Smart raised these considerations that often seem to detract from the main purpose of the relationship with the sacred, these aspects, it would appear, are vital and often support the encounter with the sacred. For as he says, the 'outer information is worth having, for without the outer forms a religion could have no inner spirit' (Smart 1977:11). 
In trying to ascertain what religion is and how it provides satisfying answers to some of the most fundamental questions on the where and why of humanity, it does still only refer to the positive features of religion and somehow the negative consequences appear to escape the definitional lenses of scholars. That is to say that these definitions of religion speak of a society without obstruction or difficulties. However, Hinde (1999:1-2) has pointed out that indeed while 'religions have helped individuals to face injustice, suffering, pain, and death', it has also been 'used to perpetuate inequalities, and religious differences have been used to justify torture, and horrific religious wars'.

But there appear to be many other grievances with religion. David Tacey (2004:36-37) has captured some of the 'strongest' and 'most fundamental' disapprovals of the structures of religion. I have summarised his thoughts as follows:

Religion is dominated by men to the exclusion of women and that is further bolstered by the ideology of a male God; the foundations of religion rest on a 'pre-modern cosmology' and an 'archaic vision of reality' which can no longer be maintained; religion is 'based on a conception of spirit that is supernatural. Spirit is conceived as an outside agency that works miracles and wonders with a "kingdom" in another reality', which is both difficult to believe and unappealing to our modern understanding; 'religion is otherworldly and transcendentalist. It does not have enough to say about the experience of the sacred in creation. It does not teach us how to live harmoniously with nature but to have power and 'dominion' over the earth. In our time of ecological crisis, what can a human-centred religion contribute to the survival of the planet?'; religion seeks faultlessness as its desired object; religion is presented to us as opposing principles and directs the spirit to 'triumph over the body and its vital desires'; religion ranks its members; 'religion rules from above, and excludes the voice of the people and democratic understanding'; religion has placed spiritual authority in the 'authority figures, priests, bishops, clergy', and people subjected themselves to such authority; religion is 'dogmatic and external to our lives'.

It 'imposes laws and rules upon us without enquiring into the nature of the self that it is transforming'; religion imposes a grand narrative upon our experiences without inquiring into the personal vignettes that constitute the course of our lives; 'religion is rejected not because a person does not believe, but because he or she is not believed. If religion expanded its horizons to include the spirituality of individuals, it might be renewed by such expansion, and individuals would not feel excluded, pushed out or irrelevant'; religion is melded with societal structures, which include business, government and those outfits engaged in trade and commerce 'to be able to offer a critique of this world'; religion does 'not allow for the true radicality of the spirit, which is always "at odds" with worldliness'; and finally, religion does not provide enough challenge to society, but simply reinforces and supports its basic values and, as such, it cannot represent the life of the spirit. (Tacey 2004:36-37)

From Tacey's list of grievances against religion, one can see the difficulties of attaining any consensus on religion, making it difficult to define; that it may very well be the assumptions and partiality of the scholar; that it is fraught with linguistic obstacles and hindrances; that religion cannot be separated from those forces that challenge its customary expression; and that there are some dominant themes that come from the more traditional ways of defining religion which allude to belief, ritual, identity, feelings and emotions.

In contrast to Tacey's negative views of religion, Preuss (1987:x) has suggested that religion '... can be understood without the benefit of clergy - that is, without the magisterial guidance of religious authorities, without "conversion" or confessional ...' or its metaphysical detours. But religious authorities are attached to religious institutions and these institutions cannot be made redundant. For example, Bruce (1996) sees the continued use of religion within society as a beneficial aspect among culturally marginalised groups such as immigrants and minority ethnic groups. In these communities, religion maintains social cohesion and cultural values. Religious institutions such as mosques and churches become community resources in these communities and provide not only worship but also social and medical care. What are institutions and why do we constantly try to get rid of them when they are part and parcel of every aspect of life and living?

According to Jensen (2014:133), an institution is a 'network of norms, rules and values' that relate to social duties and obligations. As Mary Douglas (1966:90) has pointed out, these ideas, linked to practices, are themselves institutions, and not just parts of an institution. Thus, ideas such as destiny, magic and witchcraft are institutions in themselves just as much as the modern concept of Habeas Corpus is a legal institution.

In traditional societies, the social system was governed by religiously based normative institutions, and laws as well as social rules were seen as God-given institutions that provided a 'sacred canopy', as Peter Berger (1969) put it, under which all aspects of people's lives were regulated. In a more contemporary context, Emile Durkheim (1915) sees institutions as systems of classification that regulate the lives of people both consciously and subconsciously.

Religious institutions, as social constructs through which people realise their identities, play an important role in forming people's world views, or ideological conceptions of the world. Religion thus mediates between people's physical, social and purely ideal or 'thought' worlds. Religious traditions are the means by which such religious institutions are preserved and passed on to future generations. Like languages, these traditions consist of complex cultural networks through which people engage with and understand their societies.

In contrast to these forms of religious organisation, the 'new' spirituality is not institutionalised and can therefore appear to be disorganised, though it does have its own inner logic. Separated from the constraints of religion, it takes on a much wider meaning, to the extent that it eventually becomes a very broad and loose concept that is difficult to define. Religion, on the contrary, becomes more 
narrowly conceived, while spirituality is seen to relate to the sacred aspects of life and the universe, freed from the constraints of compulsory practice and physical location (Jensen 2014:140-146).

And there are other reasons for religion which will remain important for actuality and being. Paden (1998) argues that:

Religions provide a conspicuous instance of world making because of the ontological character of their language, it is the nature of religious language to name and script the ultimate powers that determine, ground, and empower existence itself, and to fill world-experience with their meaning, agency, presence and authority. Religion is a primary cultural/ linguistic instrument for defining and exploring identity, fate, time, space, cosmic order, suffering, danger, and other metacategories. (p. 96)

There are many religions which take on many forms and there is no core aspect that will explain religion as concept. Perhaps we shall do well to take the advice of Wittgenstein (1953), who argues that 'instead of producing something common to all'...:

these phenomena have no one thing in common which makes us use the same word for all - but that they are related to one another in many different ways. And it is because of this relationship, or these relationships, that we call them all 'languages'. (p. 31)

\section{Wittgenstein (1953) continues:}

Consider for example the proceedings that we call 'games' I mean board-games, card-games, ball-games, Olympic games and so on. What is common to them all? - Don't say: 'there must be something common, or they would not be called "games" but look and see whether there is anything common to all'. - For if you look at them you will not see something that is common to all. But similarities, relationships, and a whole series of them at that. To repeat: don't think, but look! - Look for example at board-games with their multifarious relationships. Now pass to card-games: here you find many correspondences with the first group, but many common features drop out, and others appear. (p. 66)

Wittgenstein (1953) speaks about some of the common features of all games, alluding to the players, the notion of competition and amusement inherent in the game, rules, and so on, and concludes that there is no better:

expression to characterize these similarities than 'family resemblances', for the various resemblances between members of a family namely, build, features, colour of eyes, gait, temperament, etc. etc. overlap and criss-cross in the same way. (p. 67)

Perhaps these resemblances may encourage us to tease out the relationship between words and their meanings underlying our definitions of religion.

There is perhaps one feature of religion that we can say exists across all religions or systems of belief and practices using Wittgenstein's framework of resemblances, and that is consciousness. In all the definitions I have been exposed to, I do not see consciousness as a marked or distinguishing feature of religion. And yet it is present in all major religions and philosophies of the world (Needleman \& Eisenberg 1987). Consciousness suggests something other than ordinary experience.

According to these teachings, we have the potential, they claim, to experience qualitatively different levels of perception, awareness and orientation towards ourselves, others and the universe. In the ordinary existence of life:

ordinary sleep and ordinary waking consciousness constitute 'normal' human states of consciousness. Higher states correspond with finer more subtle states of consciousness. Transformation to higher states of consciousness may possibly result from adherence to the ideas, methods, and prescribed meditations of an authentic religious discipline, whereby consciousness is refined, converted and realigned from 'the coarse to the fine' characterised by enhanced faculties of attention, thought, feeling, and sensation; new ways of seeing and perception become prominent. (Needleman \& Eisenberg 1987:53)

Higher states of consciousness, on the other hand:

reflect the awakening and development of an exceptional attention and awareness, generating new powers of the self; new feelings, sensitivities, and cognitions. These, they call, 'authentic intelligence' or the 'wisdom of the heart'. It is said that this development provides unmediated contacts with reality, allowing for the comprehension and experiencing of life's meaning, value and purpose in relation to man's transcendent nature. (Needleman \& Eisenberg 1987:53)

Needleman and Eisenberg (1987) use a water metaphor to explain the quality of different states of experiences and fluctuations, and I think it is worth mentioning here to show the clear distinction between the different states of consciousness:

Whether blue, red, or clear, whether a drop, a quart, a gallon, or an ocean, whether in quiet lake or in a raging river, water is water. Its molecular arrangement remains unchanged. Ice, however, is structurally different from water. Water vapour too, represents an entirely different structural state. Its molecules move more quickly, and it is less dense and lighter. The transformation from ice to water to mist may be said to correspond to man's potential transmutation from a coarse to a finer (more ethereal) state of being. (p. 53)

However, despite the criticism of religion, it appears to be tenacious, that it is here to stay. And despite the idea that the secularisation thesis has been so prevalent, there is no fear that religion will collapse. ${ }^{7}$ As Stark and Bainbridge (1985) have said regarding the misconception of a future without religion:

$[W]$ e acknowledge that secularization is a major trend in modern times but ... this is not a modern development and does not presage the demise of religion. Secularization is a process found in all religious economies; it is something that is always going on in all societies. (p. 2)

7.The meaning of the word secularisation, derived from the Latin saeculum, has taken on different meanings over the years. As Edward Bailey (quoted in Swatos \& on different mear Christiano 1999:213) put it: 'S S ecular is really easy to define. Its meaning keeps changing yet remains consistent. It always means, simply, the opposite of "religious" - whatever that means'. More seriously, Swatos and Christiano (1999:214) explain that 'in the face of scientific rationality, religion's influence on all aspects of life from personal habits to social institutions - is in dramatic decline'. The underlying assumption was that 'people' have become 'less religious'. 
While secularisation advances in some areas of society, there is a counter force of increased religion in other parts (Stark \& Bainbridge 1985:2), witnessed by a growth in new religious movements (NRMs) between the 1960s and the 1990s which included everything from 'new age' movements to changing expressions of traditional beliefs. None of this was anticipated as we have seen in Roof's study.

Taylor (2010:3), however, has a different view of secularisation. He argues that people tend to think of secularism as the absence of religion, not something in itself, or they think of it simply as a strong separation of church and state - creating a zone of absence. These two views, he says, are at the core of the standard sociological story of secularisation. This is often seen as a cause of the decline of religion. But he introduces a third view of secularism, which focuses on:

a move from a society where belief in God is unchallenged and indeed, unproblematic, to one in which it is understood to be one option among others, and frequently not the easiest to embrace. (Taylor 2010:3)

\section{What is spirituality?}

I am partial to the idea, following Peter Van der Veer (2009:1097), that the origin of modern spirituality is a Western idea. Although older, more antique forms of spirituality may be found in mysticism, gnosticism, and hermetism, Van der Veer (2009:1097) sees it as 'wide-ranging nineteenth century transformation, a historical rupture'. What though of defining spirituality? Almost all the literature on the subject I have perused makes a similar claim that spirituality is 'notoriously hard to define', making the task as hard as it is to define religion. The word 'spirituality' from the Latin spiritualitas, which is itself a translation of the Greek noun pneuma, means spirit.

However, a few attributes suggest that it is the opposite of materiality ${ }^{8}$; that it is distinct from body; that it is different from religion; that it is distinctive from the secular epitomised in the now frequently used acronym, SBNR, which stands for: spiritual but not religious. When did this dichotomy between the material and the non-material take place? This development apparently can be traced to the translation of the terms pneuma and pneumatikos, which St. Paul employed to suggest that which is opposite to the flesh (sarx) but not to the body (soma or corpus). The flesh, therefore, is not to be perceived as the human body, 'but it represents everything in human beings that opposes the influence of the Spirit of God' (King 2009:7). It was during the 12th century that the word spirituality came to take on a meaning that would suggest an opposition to corporality, materiality, carnality and mortality (King 2009:7). The word made its entry into the English language from $1500 \mathrm{CE}$ onwards. Spirituality today attempts to reconcile 'spirit and body, sacredness and sexuality together in a redemptive experience of the totality and mystery of life' (Tacey 2004:36-37).

8.Plato (Hutchins 1952:466) posits in the Timaeus the idea that humankind possesses an immortal soul in a mortal body, alluding to a separation between spirit and material.
Sheldrake (2005) writing in a very specific context of spirituality from a Christian perspective says that 'Christian spirituality embodies a conscious relationship with God, in Jesus Christ, through the indwelling of the Spirit, in the context of a community of believers'. However, this was not always the way in which spirituality as a concept was perceived; earlier meanings 'tended to see a distinction between spiritual and material levels of human existence, between "interiority" or a life of prayer and an outer everyday public life' (Sheldrake 2005:introduction). And perhaps this is where some fault lines lie when comparing spirituality to the concept of religion; both had dichotomous tendencies in that it separated and compartmentalised the material over the spiritual, and the private over the public. However, this view of spirituality has changed in the last 20 years or more, and it has begun to embrace the whole of human life - albeit from the perspective of a relationship with God' (Sheldrake 2005:introduction).

I have shown above in Roof's Generation of Seekers how the religious landscape shortly after the war had changed and how the boomers took personal responsibility for their relationship with the sacred. What follows is an explanation of how a 'conversion' occurs in people who abandon religious affiliation and take up spirituality. According to Tacey (2004:106-107), there are 'certain patterns' which he is eager to call 'archetypal' which display universal patterns that recur in these changes from one relationship with the sacred to another:

1. Natal faith: one is born into a particular faith and inducted into its religious traditions and institutions.

2. Adolescent separation: questions are asked and no adequate answers are given.

3. Secular identification: lost contact with natal faith and or renounced institutional affiliation. Also, there be a denouncement of faith and the person sees himself or herself as a secular humanist, agnostic or atheist. The parents of this person may have also relinquished ties with matters regarding religion and so left the child to make up its own mind.

4. Secular disillusionment: the transition to secular society does not fulfil the person. It presents the person with more consumerism such as holidays, entertainment and so on, and very little by way of the sacred.

5. Adult secular spirituality: the child then develops his or her own secular spirituality outside his or her known religious influences which may include church, synagogue, temple and so on.

Why exactly are people, who were once-upon-a-time religious, dissatisfied with religion, and what are they converting to?

The main problem that is articulated by many is that more and more people are unhappy and find unsatisfactory 'narrow dogmatic religious views' and who are 'frustrated with strictly rationalistic worldviews and life goals' (Forman 2004:2). What many people are calling for, according to 
Forman's participants, ${ }^{9}$ is not so much about the structure of community but the structure of the content of their beliefs. In other words, the participants of his study want to have their own narratives regarding their spirituality and beliefs. That is to say, that they don't want the control of religious structures (Forman 2004:177).

But it would appear from Forman's study, that spirituality is equally fraught with the difficulties of defining. And again, like religion, Forman argues that ' $[L]$ inguistically ... "spirituality" tends to be a space-holder in a series of dualisms: The spiritual over against the rational, the dogmatic, the formal church, etc.' (Forman 2004:177). Be that as it may, the movement from religion to spirituality is a very real one - one we should be taking note of. As Robert Redfield (quoted in Forman 2004) says:

There are many more of us out there than any of us really know. What is happening in the world, in my view, is that there is a new spiritual awareness. We are in the consensus building process about who we are as human beings, who we are as spiritual beings. (p. 7)

Furthermore, there is a 'new' awareness of other religions and religious systems that appear to contradict the secularisation thesis. According to Taylor (2012:174), the barriers that once existed between the various religions are 'breaking down'. This is a major feature of the new spiritual landscape which is allowing people to express themselves beyond traditional Christian conformity. What's more, says Taylor (2012:175), is that practitioners of spirituality are adopting new ways of relating to other religions such as 'combining Christianity with Buddhism' - all practices that would have been seen as 'untenable' under the dispensation of religion. Similarly, as Kalsky (2017) has argued, there is a radical religious transformation through secularisation, individualisation and migration in the Netherlands that has produced hybrid forms of religiosity incorporating other religions These multiple religious belongings (MRB) have presented a challenge to traditional concepts of religious identity and belonging (Kalsky 2017:345). William James (2002 [1902]:xv) too recognised this when he said that 'divinity lies all around us, but society remains too hidebound to accept that fact'.

This breakdown in barriers between the religions that Taylor addresses has been a result of a 'profound crisis of meaning' that has occurred because of numerous wars, deep injustices in the world and ecological disasters that have prompted a new thinking and indeed, 'transformative ways of thinking' (King 2009:viii). These calamities need 'a more reverent attitude toward people and the planet' and therefore 'calls for a spirituality that will lead to the reorganisation of world economics, politics, education, business, and world governance' (King 2009:viii).

9. Forman's (2004) methodology employs key informant technique, which means that he has drawn on people in his intervisws who have a position in socicty knowledge and personality which put them in a key position to speak about the grassroots and personality which put them in a key position to speak about the grassroots spirituality movement. Ninety two individuals were selected to be part of a proces which involved structured but flexible interviews. It is an important study that has implications for scholars working in all fields of religion and spirituality.
The same difficulty that underlies defining the concept of religion exists in defining spirituality. One such difficulty is whether we can speak of spirituality in the singular. Tirkey (2006:11) sees spirituality as a diverse concept existing among all of humanity. He argues that there is not 'one uniform concept or experience of spirituality'. 'We have', he continues, 'different cultural and religious backgrounds, different socio-economic and political situations, varied psychological conditionings - all these contribute to the plurality of spiritualities'.

Similarly, the definitional net can be so vast that it may include all types of phenomena. For example, Tacey's (2004) view of spirituality is so wide which he sees as a cure to many things which among them include racism, which he sees as an essential ingredient of the new ecological awareness, an antidote to domestic violence and civil unrest, and a remedy for religious sectarianism and holy wars. Spirituality is about engagement with the world and nature, a renewed sense of justice for humans. While it is internal and personal in so far as experiences go, it is not shut away from the reality of this world (Tacey 2004:66). Through genuine spiritual experience, we are released from the burden of ego, and discharged into a larger world that enables us to focus less on our ego and more on our larger cosmic identity. This shift, he argues, gives us space and opportunity to reduce our 'egoic tension and to shed hostilities associated with being a victim or an alienated self'. In other words, it allows us to love rather than to hate. And I think here is the essence of what Tacey is saying which echoes what Ursula King has said: 'Spirituality is about personal empowerment, but it is not "private" because from this transformation will flow political and social transformations' (Tacey 2004:66). So this is a far cry from what humans do with their solitariness.

However, Tacey (2004:88) has acknowledged that there is a growing need for 'internal, personal-based spiritual experience' which may not necessarily be seen as a 'weakening of religion but an intensification of religion as intimate personal experience'. Tacey sees the dropping of the ego as a spiritual practice that is akin to Eastern philosophies and religions, which he argues show more sophistication than Western religions. But one doesn't necessarily have to go east to explore these spiritual practices. What he argues is that:

we already have highly developed mystical traditions involving interiority and the exploration of the God within. What we have to do is draw these traditions from their historical obscurity and into the light of the present. (Tacey 2004:88)

So there appears to be in the practice and adoption of spirituality a departure from the previous order having farreaching consequences that are being registered in the human heart and personal identity. And this is related to the breaking down of secular structures in society. How is this so? For Tacey (2004), the answer lies in history.

We are by nature religious beings, and the secular modern period has witnessed a general repression of our sense of the spirit. After a self-imposed ban we are remembering our sacredness and our dormant religious life is awakening. (p. 18) 
The secular period was born out of humanism and the enlightenment as were our knowledge institutions, 'and as such they do not reach out beyond the present or show us a way into the future' (Tacey 2004:18).

But how has religion responded? Tacey (2004) says that formal religion is somewhat stupefied and bewildered by these 'turbulent times' and by this shift of social direction. Religion, he continues:

is so used to being self-protected, so smarting under the attacks of science, reason and secularism, so deeply withdrawn into its defensive cocoon, that it can hardly imagine that the people really do need the gifts of the spirit. The conservative elements in religion are quite suspicious of what is currently taking place; they suspect that this new taste for spiritual nourishment is just another consumer fad or fashion of a desperate society. (pp. 19-20)

Furthermore, Western religions are very critical of this new spirituality 'especially as this popular movement is not "churchy" and does not fit in with formal religious expectations' (Tacey 2004:19-20).

Mircea Eliade (1969:preface) was also not too optimistic 'about the ability of formal religion to recognise the sacred in secular society'. Writing about the youth and hippy culture of the 1960s, Eliade (1969:preface) commented that the sacred was making a new appearance in the world, but that the Judeo-Christian traditions were incapable of recognising it:

In the most radically secularised societies and among the most iconoclastic contemporary youth movements (such as the hippy movement, for example), there are a number of apparently nonreligious phenomena in which one can decipher new and original recoveries of the sacred; although, admittedly, they are not recognisable as such from a Judeo-Christian perspective. (Eliade 1969:preface)

Is it not perhaps that the old religious traditions often dislike the new forms of expressions, not only because the new ways of approaching the sacred challenge old established ways but because the 'old religion thinks of itself as complete and absolute?' (Tacey 2004:18, the question is mine)

\section{Conclusion}

In this article, I set out to show that the predictions made just over 100 years ago that religion would disappear and that science would triumph did not actually happen. This view that the world would secularise because religion was at odds with modern living dominated the sociological view in the 19th century until it began to be challenged shortly after the Second World War from the 1960s. What indeed did happen was that both its critics and defenders have agreed that religion is faring well and is here to stay despite the effects of secularisation.

However, it was Wade Clark Roof's 1993 empirical study, A Generation of Seekers, that made scholars aware of the shift that had taken place in the religious landscape; the relationship with the sacred took on new forms that would alter future trends in religion and at the same time showed a departure from the previous order. ${ }^{10}$

I have shown how notoriously difficult it is to define both religion and spirituality and to point out the differences between them. What is clear is that spirituality is closely connected with religion 'but not exclusively contained by it', to use Ursula King's (2009) words. The adherents of spirituality criticise religion for its archaic teachings that are patriarchal and dogmatic; imposing rules from above; being hierarchical; placing its authority in priests, bishops and clergy; and being generally institutional, making it narrow, rigid, prescriptive and less attractive. Furthermore, in the classification of religion, the dichotomous agenda of polarity and separation has been most detrimentally put to use, thereby separating the sacred from the profane.

Spirituality, on the contrary, has been lauded for seeing the unity of the sacred, human beings and nature, which largely includes politics, the environment and the socio-cultural milieu, and in this agenda providing a holistic approach and presenting its adherents with an all-encompassing worldview. It has, further, been known to break down barriers between the different religions, thereby giving it a breadth of vision that provides an à la carte range, to use a food metaphor, of choices between beliefs and practices that individuals can now make themselves without the aid of a religious institution that autocratically serves up dishes of dogma and creed to its adherents.

However, spirituality may also be criticised for not having a core of religious meaning, and perhaps a 'sacred canopy', to use Peter Berger's phrase, that can act as a unifying structure. The concern is that the spirituality adherents now long for community - something they find they would love to have because they want to meet people who are like them in practice. However, the problem with this is that it could end up becoming an institution - the very thing that they objected to in the religious domain.

Perhaps, further empirical research is needed to ferret out more accurate definitions of the concept of spirituality and to find out more about what exactly people mean when they say they are spiritual. After all, that would be more in keeping with the spirit of spirituality, and it will also produce a more authentic idea of what spirituality is.

\section{Acknowledgements Competing interests}

The author declares that she has no financial or personal relationships which may have inappropriately influenced her in writing this article.

10. However, Peter Berger (1967:131) also raised the issue that '... secularisation has resulted in a widespread collapse of the plausibility of traditional religious definitions of reality'. 


\section{References}

Berger, P.L., 1967, The social reality of religion, Penguin Books, Great Britain

Berger, P.L., 1969, The sacred canopy: Elements of a sociological theory of religion Doubleday, Garden City, NY.

Beyer, P., 2006, Religions in global society, Routledge, London.

Borowik, I., 2011, 'The changing meanings of religion. Sociological theories of religion in the perspective of the last 100 years', International Review of Sociology 21(1), 185-189, viewed 10 April 2018, from https://www.researchgate.net/publication/ 233153669

Bruce, S., 1996, Religion in the modern world: From cathedrals to cults, Oxford University Press, Oxford.

Caputo, J.D., 2000, On religion, Routledge, London.

Cassirer, E., 1968, The philosophy of the enlightenment, Princeton University Press, Princeton, NJ.

DiCenso, J.J., 1998, 'Religion and the psycho-cultural formation of ideas', in T.A Idinopulos \& B.C. Wilson (eds.), What is religion? Origins, definitions, and explanations, pp. 15-25, Brill, Leiden.

Douglas, M., 1966, Purity and danger, Routledge \& Kegan Paul, London.

Durkheim, E., 1915, The elementary forms of the religious life, The Free Press, George Allen \& Unwin Ltd, Glencoe.

Eliade, M., 1969, The quest: History and meaning in religion, The University of Chicago Press, Chicago, IL.

Forman, R.K.C., 2004, Grassroots spirituality: What it is. Why it is here. Where it is going? Imprint Academic, Exeter.

Geertz, C., 1971, Islam observed: Religious development in Morocco and Indonesia, University of Chicago Press, Chicago, IL.

Hick, J., 2004, An interpretation of religion: Human responses to the transcendent, 2nd edn., Palgrave Macmillan, New York.

Hinde, R.A., 1999, Why gods persist: A scientific approach to religion, Routledge, London.

Hutchins, R.M. (ed.), 1952, 'Timaeus', in Great books of the western world: The dialogues of Plato, transl. B. Jowett, pp. 442-477, William Benton, Chicago, IL.

Idinopulos, T.A., 1998, 'The difficulties of understanding religion', in T.A. Idinopulos \& B.C. Wilson (eds.), What is religion? Origins, definitions, and explanations, pp. 27-42, Brill, Leiden.

James, W., 1929, The varieties of religious experiences, Modern Library Edition New York.

James, W., 2002 [1902], Varieties of religious experience: A study in human nature, Centenary Edition, Routledge Taylor \& Francis Group, London.

Jensen, J.S., 2014, What is religion? Acumen Publishing Ltd., UK.

Kalsky, M., 2017, 'Flexible believers in the Netherlands: A paradigm shift toward transreligious multiplicity', Open Theology 3, 345-359, viewed 11 March 2018 , from https://research.vu.nl/ws/files/37159875/M_Kalsky_Flexible_believers_in the Netherlands_De_Gruyter_opth.pdf.

King, U., 2009, The search for spirituality: Our global quest for a spiritual life, Canterbury Press, Norwich.

King, W.L., 1987, 'Religion', in M. Eliade (ed.), The encyclopedia of religion, vol. 12 pp. 283-293, Macmillan Publishing Company, New York.

Mackay, D.B., 2000, 'Ethnicity', in W. Braun \& R.T. McCutcheon (eds.), Guide to the study of religion, pp. 96-109, Cassell, London.

Needleman, J. \& Eisenberg, R., 1987, 'Consciousness, states of', in M. Eliade (ed.), The encyclopedia of religion, vol. '12, pp. 53-59, Macmillan Publishing Company, New York.
Niebuhr, R., 1968, in D. Cutler (ed.), The religious situation, Preface, p. x, Beacon Press, Boston, MA.

Olson, C., 2003, Theory and method in the study of religion: A selection of critical readings, Thompson and Wadsworth, Belmont, CA.

Otto, R., 1958, The idea of the holy, Herder and Herder, New York.

Otto, R., 2003, 'The idea of the holy', in C. Olson (ed.), Theory and method in the study of religion: A selection of critical readings, pp. 107-124, Thomson Wadsworth, Australia, Belmont, CA.

Paden, W.E., 1998, 'Religion, world, plurality', in T.A. Idinopulos \& B.C. Wilson (eds.) What is religion? Origins, definitions, and explanations, pp. 91-105, Brill, Leiden.

Preuss, S.J., 1987, Explaining religion: Criticism and theory from Bodin to Freud, Yale University Press, New Haven, CT.

Ramsey, E. \& Ledbetter, S., 2001, 'Studying religion: Issues in definition and method', in I.S. Markam \& T. Ruparell (eds.), Encountering religion: An introduction to the religions of the world, pp. 1-14, Blackwell Publishers, Oxford, UK.

Roof, W.C., 1993, A generation of seekers: The spiritual journeys of the baby boom generation, Harper, San Francisco, CA.

Sheldrake, P. (ed.), 2005, The new SCM dictionary of Christian spirituality, SCM Press, London.

Smart, N., 1977, The long search, Little Brown and Company, Boston, MA.

Smith, B.K., 1989, Reflections on resemblance, ritual, and religion, Oxford University Press, Oxford.

Smith, H., 2001, Why religion matters: The fate of the human spirit in an age of disbelief, Harper, San Francisco, CA.

Stark, R. \& Bainbridge, W.S., 1985, The future of religion: Secularization, revival and cult formation, University of California Press, Berkeley, CA.

Strenski, I., 1998, 'On "religion" and its despisers', in T.A. Idinopulos \& B.C. Wilson (eds.), What is religion? Origins, definitions, and explanations, pp. 113-132, Brill, Leiden.

Swatos, W.H. \& Christiano, K.J., 1999, 'Secularization theory: The course of a concept', Sociology of Religion 60(3), 209-228.

Tacey, D., 2004, The spirituality revolution: The emergence of contemporary spirituality, Routledge Taylor and Francis Group, London.

Taylor, C., 2010, 'The meaning of secularism', The Hedgehog Review, viewed 10 March 2018, from http://iasc-culture.org/THR/archives/Fall2010/Taylor_lo.pdf.

Taylor, C., 2012, 'Extract "Religion Today”', in P. Heelas (ed.), Spirituality in the modern world: Within religious tradition and beyond. Critical concepts in religious studies, pp. 168-176, Routledge Taylor \& Francis Group, London.

Tillich, P., 1959, Theology of culture, Oxford University Press, New York.

Tirkey, C.A.B., 2006, An outline of spirituality, The Indian Society for Promoting Christian Knowledge, Delhi.

Tylor, E.B., 1891, Primitive culture: Researches into the development of mythology, philosophy, religion, language, art, and custom, J. Murray, London.

Van der Veer, P., 2009, 'Spirituality in modern society', Social Research 76(4), 1097-1120, viewed 14 April 2018, from http://www.urbanlab.org/articles/van der_Veer_Social-Research-1097-1120.pdf.

Weber, M., 1963 [1922], The sociology of religion, transl. E. Fischoff, Beacon Press, Boston, MA.

Whitehead, A.N., 1926, Religion in the making, Cambridge University Press, New York.

Wilson, B.C., 1998, 'From the lexical to the polythetic: A brief history of the definition of religion', in T.A. Idinopulos \& B.C. Wilson (eds.), What is religion? Origins, definitions, and explanations, pp. 141-162, Brill, Leiden.

Wittgenstein, L., 1953, Philosophical investigations, transl. G.E.M. Anscombe, Basil Blackwell, Oxford, UK.

Yinger, M.J., 1970, The scientific study of religion, MacMillan Publishing Co., New York. 